\title{
Suitability of Foumban Clays (West Cameroon) for Production of Bricks and Tiles
}

\author{
Abiba Mefire Nkalih',2, Pascal Pilate ${ }^{3}$, Rose Fouateu Yongue ${ }^{2 *}$, André Njoya4, Nathalie Fagel ${ }^{1}$ \\ ${ }^{1}$ Laboratory of Clays, Geochemistry and Sedimentary Environments (AGEs), Department of Geology, University of Liège, \\ Quartier Agora, Liège, Belgium \\ ${ }^{2}$ Laboratory of Applied Geology-Metallogeny, Department of Earth Sciences, University of Yaoundé I, Yaoundé, Cameroon \\ ${ }^{3}$ Belgian Ceramic Research Center, Mons, Belgium \\ ${ }^{4}$ Fine Arts Institute of Foumban, University of Dschang, Foumban, Cameroon \\ Email: *rfyongue@yahoo.fr
}

How to cite this paper: Mefire Nkalih, A., Pilate, P., Yongue, R.F., Njoya, A. and Fagel, N. (2018) Suitability of Foumban Clays (West Cameroon) for Production of Bricks and Tiles. Journal of Minerals and Materials Characterization and Engineering, 6, 244-256.

https://doi.org/10.4236/jmmce.2018.62018

Received: December 24, 2017

Accepted: March 23, 2018

Published: March 26, 2018

Copyright $\odot 2018$ by authors and Scientific Research Publishing Inc. This work is licensed under the Creative Commons Attribution International License (CC BY 4.0).

http://creativecommons.org/licenses/by/4.0/

Open Access

\begin{abstract}
Particle size analysis, Atterberg limits, X-ray diffraction, X-ray fluorescence and firing tests were used to determine physico-chemical, mineralogical and technological characteristics of residual lateritic (K1M, Ma2) and alluvial (KB3, KG3) clays from Foumban (West-Cameroon). For technological properties, the samples were pressed and fired over a temperature range of $900^{\circ} \mathrm{C}$ $1200^{\circ} \mathrm{C}$ to determine the open porosity, linear shrinkage, bulk density and compressive strength. Kaolinite $(31 \%-65 \%)$ and quartz $(35 \%-50 \%)$ are dominant in Foumban clays with accessory K-feldspar, plagioclase, illite, smectite, rutile, and goethite. But their proportion changes from one sample to another, having a significant effect on the behaviour of the clay materials: highest proportion of quartz $(50 \%)$ in sample $\mathrm{K} 1 \mathrm{M}$; relative high feldspars (20\%) and illite contents (10\%) in KB3 and MA2; high smectite content in $\mathrm{KG} 3$ (up to 20\%). Chemical analyses indicate high $\mathrm{SiO}_{2}(49 \%-77 \%)$ and low $\mathrm{Al}_{2} \mathrm{O}_{3}(14 \%-23 \%)$ contents in the four samples, with comparatively low contents of iron oxides $(4 \%-7 \%$ in samples $\mathrm{KB} 3$ and $\mathrm{KG} 3,2.5 \%$ in MA2 and $\sim 1.5 \%$ in sample $\mathrm{K} 1 \mathrm{M})$. The particle size distribution of the alluvial clays (KG3 and KB3) differs considerably: $7 \%$ to $37 \%$ of clay fraction, $20 \%$ to $78 \%$ of silt, and $15 \%$ to $58 \%$ of sand, while residual clays (K1M and MA2) present on average $12 \%$ of clay, $51 \%$ of silt and $37 \%$ of sand. Two raw clays (KB3 and MA2) can be used for bricks/tiles production without beneficiation or addition. K1M requires some flux addition to decrease the sintering temperature while KG3 presents poor properties due to the combined occurrence of smectite and a high clayey fraction (37\%). Such mineralogical composition is responsible for very high plasticity (PI: 50 ), high shrinkage (LS: 5\% - 16\%), low porosity (OP: up to $21 \%$ ) and high flexural strength (FS: $16-23 \mathrm{~N} / \mathrm{mm}^{2}$ )
\end{abstract}


above $1050^{\circ} \mathrm{C}$. This last clay is therefore less appropriate for bricks and roofing tiles production since degreasers must be added to the raw material.

\section{Keywords}

Clay Materials, Ceramic Properties, Physical Characterization, Bricks, Tiles, Cameroon

\section{Introduction}

Clays have been used in a wide range of ceramic products as a major component in most ceramic bodies [1]. Clays are important raw material for construction such as bricks due to many specific characteristics before (mineralogy, plasticity and particle size distribution) and after firing (mineralogy, porosity, mechanical strength) [2]. The suitability of a clay for fired bricks depends on its behavior during shaping, drying and firing [2]. This behavior determines the final properties of bricks, especially their porosity and durability [1]. Thus, the characterization and quality control of clay is important for the technical performance of local products. Also, distinct layers associated with different clays can be found in a specific deposit; therefore, the mixture of various clays will permit to adjust the properties of both the unfired body and corresponding final product [3].

In Foumban (West Cameroon), clay raw materials display a widespread distribution and they have been exploited for the traditional production of small-scale ceramic products (pottery, bricks). In particular, clay materials from the localities of Marom and Koutaba, located eastern and southern Foumban respectively, are both residual and alluvial [4]. Residual lateritic clay material appears in yellowish to red color, and up to $15 \mathrm{~m}$ thick; alluvial clay materials appear in grey brown to grey green in color and less thick, 2 - $6 \mathrm{~m}$ thick. Mineralogical studies show that clay minerals $(22 \%-97 \%)$ and quartz $(2 \%$ $63 \%)$ are dominant in these two materials. Foumban clay is a primary material for local ceramic manufacturers but no detailed study of the properties of fired bricks has been made. A complete characterization of the precursor clays as a function of the firing temperature is needed. The aim of the present paper is to associate the mineralogical and chemical composition of clay materials to ceramic properties (linear shrinkage, open porosity, bulk density, and compressive strength) during firing in order to evaluate the applicability in fired bricks and tiles.

\section{Material and Methods}

\subsection{Material}

Foumban raw clays can be divided into two groups based on field observations: homogeneous clayey laterite in the upper part of a laterite cover on interfluves (e.g. at Marom and Koutaba) and heterogeneous hydromorphic clayey material 
in the valley (e.g., at Koutaba) [4]. Figure 1 shows coring localization on the geological map of the studied area. Koutaba and Marom clay deposits derive from the weathering of the Panafrican granite basement [5] [6]. Weathered granitic rocks are predominant sources, and, to certain extend, Eocene volcanic rocks. Four clay materials resulting from the homogenization of different clay varieties per profile were taken into consideration. The clay $\mathrm{K} 1 \mathrm{M}$ represents the average profile of 11 Koutaba residual kaolin samples labelled (K1b1 toK1b11, Table 1). The clay KB3 (average of 5 samples labelled KB3a to KB3e, Table 1) and KG3 (average of 7 samples labelled KG3a to KG3g, Table 1) are the average profile of Koutaba grey-brown and grey-green alluvial clays. At Marom, the clay MA2 corresponds to the average profile of 5 layers (labelled MA2a to MA2e, Table 1).

\subsection{Methods}

The raw clay samples were dried in an oven at $40^{\circ} \mathrm{C}$ for 24 hours. They were characterized by XRD, chemical analyses (XRF), particles size distribution (PSD) and plasticity. Firing test including linear shrinkage, open porosity, dry bulk density and compressive strength were evaluated for fired press.

The X-ray diffraction (XRD) patterns were obtained with a Bruker D8-Avance Eco $1 \mathrm{Kw}$ diffractometer (Copper K $\alpha$ radiance, $\alpha=1.548 \AA, V=40 \mathrm{Kv}, I=25 \mathrm{~mA}$ )

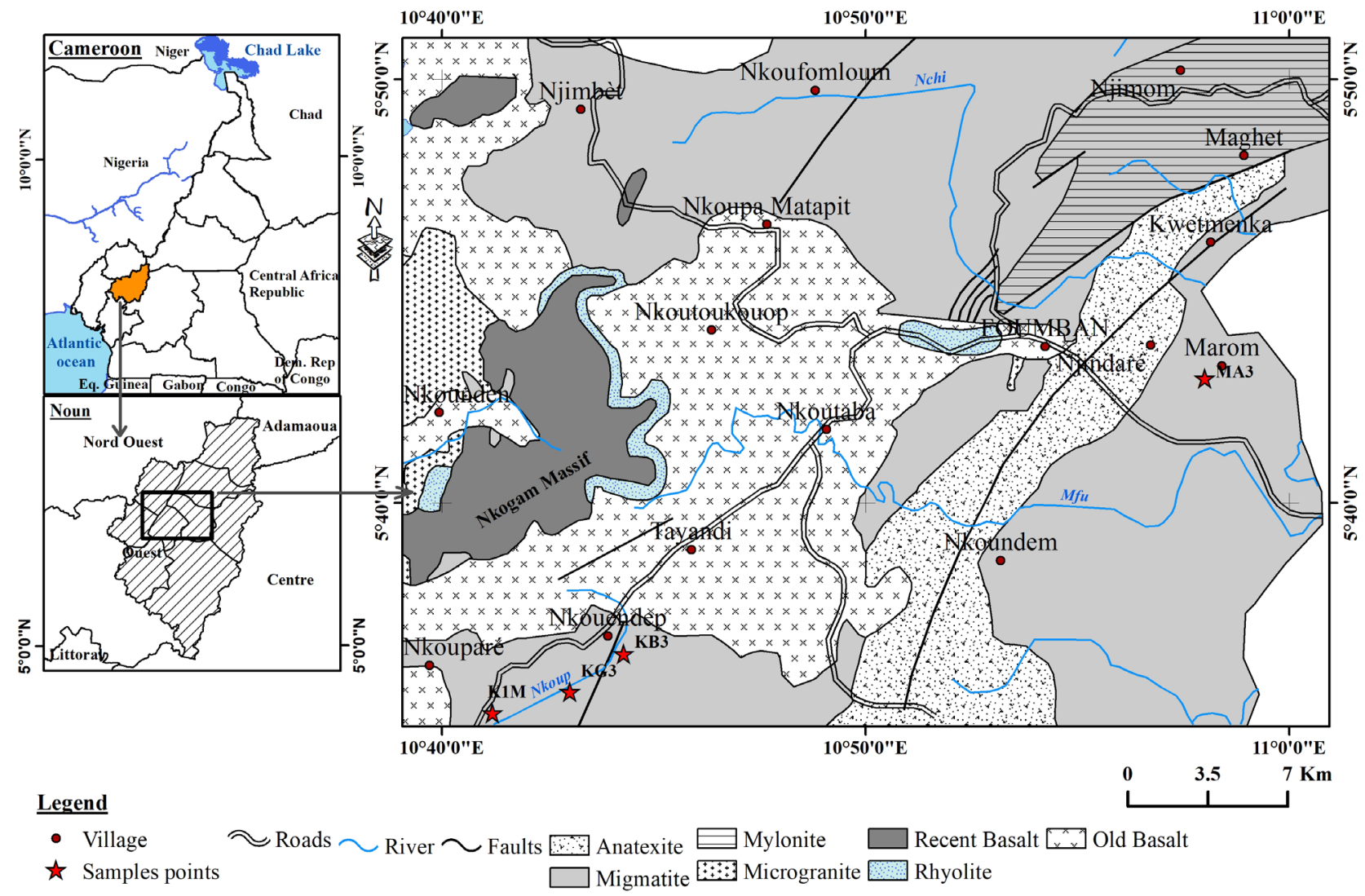

Figure 1. Location of the studied samples on the geological map of Foumban. 
Table 1. Description of studied clay samples; depth (m) and mineralogical composition (\%).

\begin{tabular}{|c|c|c|c|c|c|c|c|c|c|c|}
\hline Sample & Depth & Clays & Quartz & K-F & Plag. & Rut. & Goe. & Kao. & Illite & Smec. \\
\hline $\mathrm{K} 1 \mathrm{M}$ & 3 & 44 & 50 & - & - & - & 6 & 32 & 12 & - \\
\hline K1b1 & 0.1 & 44 & 56 & - & - & - & - & 44 & 28 & - \\
\hline K1b2 & 0.5 & 92 & 1 & 4 & - & - & 3 & 82 & 10 & - \\
\hline K1b3 & 1.2 & 42 & 54 & 4 & - & - & - & 32 & 13 & - \\
\hline K1b4 & 1.5 & 44 & 52 & - & - & - & 4 & 31 & 13 & - \\
\hline K1b5 & 1.6 & 44 & 55 & - & - & - & 1 & 32 & 12 & - \\
\hline K1b6 & 1.95 & 46 & 150 & - & - & - & 4 & 36 & 10 & - \\
\hline K1b7 & 2 & 41 & 57 & - & 2 & - & - & 30 & 10 & - \\
\hline K1b8 & 2.1 & 40 & 54 & - & 4 & - & 2 & 27 & 5 & - \\
\hline K1b9 & 2.4 & 20 & 75 & - & - & - & 5 & 14 & 16 & - \\
\hline K1b10 & 2.5 & 53 & 47 & - & - & - & - & 37 & 15 & - \\
\hline K1b11 & 2.8 & 46 & 54 & - & - & - & - & 31 & 28 & - \\
\hline MA2 & 5.2 & 48 & 32 & 15 & 5 & - & - & 31 & 14 & 3 \\
\hline MA21 & 0.4 & 60 & 15 & 11 & 13 & - & - & 45 & 12 & 3 \\
\hline MA22 & 0.6 & 45 & 33 & 20 & 3 & - & - & 24 & 17 & 4 \\
\hline MA23 & 2.5 & 28 & 50 & 19 & 3 & - & - & 16 & 11 & 1 \\
\hline MA24 & 0.6 & 26 & 44 & 26 & 4 & - & - & 16 & 8 & 2 \\
\hline MA25 & 0.4 & 63 & 26 & 7 & 4 & - & - & 39 & 21 & 3 \\
\hline KB3 & 5 & 50 & 32 & 13 & 3 & 2 & - & 40 & 6 & 4 \\
\hline KB31 & 0.9 & 47 & 42 & 7 & 4 & - & - & 33 & 10 & 3 \\
\hline KB32 & 1 & 56 & 39 & 5 & - & 2 & - & 45 & 10 & \\
\hline KB33 & 1 & 35 & 37 & 5 & 23 & 3 & - & 27 & 5 & 3 \\
\hline KB34 & 0.8 & 0 & 48 & 47 & 4 & - & - & 40 & 7 & 1 \\
\hline KB35 & 0.5 & 50 & 24 & 26 & - & 4 & - & 50 & - & - \\
\hline KB36 & 0.5 & 79 & 21 & - & - & 5 & - & 40 & 13 & 25 \\
\hline KG3 & 5.2 & 75 & 20 & 2 & - & 1 & 2 & 50 & 5 & 20 \\
\hline KG31 & 0.3 & 59 & 34 & 6 & - & - & - & 43 & 10 & 4 \\
\hline KG32 & 1.1 & 61 & 19 & - & - & 3 & 17 & 49 & 2 & 11 \\
\hline KG33 & 0.3 & 88 & 10 & - & - & - & 2 & 62 & 3 & 23 \\
\hline KG34 & 0.6 & 78 & 22 & - & - & - & - & & & \\
\hline KG35 & 1.3 & 86 & 11 & 3 & - & - & - & & & \\
\hline KG36 & 0.9 & 59 & 40 & 1 & - & - & - & 30 & 5 & 24 \\
\hline KG37 & 0.3 & 81 & 15 & 3 & - & 2 & - & 32 & 18 & 31 \\
\hline
\end{tabular}

$\mathrm{K}-\mathrm{F}=$ alkali feldspars; $\mathrm{Plag}=$ plagioclase; Rut $=$ rutile; $\mathrm{Goe}=$ goethite; Kao $=$ kaolinite; $\mathrm{Sm}=$ smectite. 
with LynxeyeXe energy dispersive (one dimensional coupled $2 \theta / \theta$ detector with 3.28) in the laboratory of "Argiles, Géochimie et Environnements sédimentaires (AGEs)" at the University of Liège, Belgium. The analyses were carried out on the non-oriented powder with grinded particles $<250 \mu \mathrm{m}$ (bulk material) and the oriented powder $<2 \mu \mathrm{m}$ (clay fraction) according to [7]. Eva software was used for the mineral phase analysis. The semi-quantitative relative abundance of minerals was estimated using the height of a diagnostic peak multiplied by a corrective factor [8] [9] [10] in combination with the $100 \%$ approach (the term $100 \%$ approach connotes that the sum of all phase quantities identified in a sample is $100 \%$ ) [11] and an estimated uncertainty of $\pm 5 \%-10 \%$ [12]. The chemical analyses of major elements were carried out by X-ray Fluorescence Spectrometry ARL PERFORM-X 4200 (standard error $<1 \%$ ) after Loss of Ignition (LOI) measurement at $1000^{\circ} \mathrm{C}$. The particle size distribution was determined by wet sieving for the $\geq 100 \mu \mathrm{m}$ fraction and gravity sedimentation for $<100 \mu \mathrm{m}$ fraction. The Casagrande method helped to determine the Atterberg limits according to the ASTM D-422 and D-4318 norms respectively [13] [14].

For firing test, homogeneous mixture pieces $(24 \times 23 \times 25 \mathrm{~mm})$ were obtained by uniaxial pressing of a clay powder $(20 \mathrm{~g})$ at $(45,73 \mathrm{Mpa})$ with a Graseby-Specac apparatus at the Belgian Ceramic Research Center (BCRC), Mons-Belgium. The firing stage took place at the temperature $900^{\circ} \mathrm{C}-1200^{\circ} \mathrm{C}$, at the intervals of $50^{\circ} \mathrm{C}$. The high pressing loads in dry process tends to increase the bending strength and reduce the shrinkage of fired bodies [15] [16]. The firing properties for all fired specimens were evaluated. The linear shrinkage $100\left(L_{m}-L_{f}\right) / L_{m}$ were obtained according to the relative variation length of the specimen, where $L_{m}$ is the length of the mould and $L_{f}$ that of the fired specimen. The compressive strength of fired clay bricks was measured according to the ASTM C377-88 standard [17]. Archimede's method based on ASTM C373-88 [18] helped to determine the open porosity and bulk density.

\section{Results and Discussion}

\subsection{Mineralogical and Physico-Chemical Characterization}

XRD patterns of the investigated clays are characterized by the peaks of quartz and kaolinite (Figure 2). This is the case for most clays resulting from the weathering of acid rocks such as granites [3] [19]. The characteristic peaks of $\mathrm{K}$-feldspar, plagioclase, illite, smectite, rutile, and goethite are also identified, but they usually show small intensities (data in Table 1) except MA2 (for K-feldspar and plagioclase) and KG3 (for smectite). On the basis of semi-quantitative method, kaolinite $(31 \%-65 \%)$ and quartz $(35 \%-50 \%)$ are dominant in Foumban clays but their proportions vary from one sample to another. For example, the highest proportion of quartz $(50 \%)$ is observed in the Koutaba residual clay sample $(\mathrm{K} 1 \mathrm{M})$, as indicated by the high $\mathrm{SiO}_{2} / \mathrm{Al}_{2} \mathrm{O}_{3}$ ratio (5) and low LOI (5\%, Table 2). Samples KB3 and MA2 are characterized by the relative high K-feldspar, plagioclase (20\%) and illite contents (10\%). Smectite content is high 
in KG3 (up to $20 \%$ ).

Chemical analyses allowed a rapid classification of the studied clays. The high $\mathrm{SiO}_{2}(49 \%-77 \%)$ and low $\mathrm{Al}_{2} \mathrm{O}_{3}(14 \%-23 \%)$ contents, are in agreement with the proportion of kaolinite [3] [20]. This high proportion of $\mathrm{SiO}_{2}$ observed in $\mathrm{K} 1 \mathrm{M}$ may have a high abrasion effect on the applied finished products like bricks and tiles, therefore it should be reduced. Iron oxides $\left(\mathrm{Fe}_{2} \mathrm{O}_{3}\right)$ account for the color of firing products [21]. The comparatively low content of iron oxides in samples KB3 and KG3 (4\% - 7\%, Table 2) is suitable for bricks production; their low content in sample $\mathrm{K} 1 \mathrm{M}(\sim 1.5 \%)$ inducing their white or whitish color after firing is in favor of porcelain, sanitary wares and/or tableware production [1]. In MA2 (2.5\%), the iron oxide is likely more consistent with their use in roofing tiles and rustic floor tiles [2]. During firing, earth alkali oxides ( $\mathrm{CaO}, \mathrm{MgO})$, alkali oxides $\left(\mathrm{K}_{2} \mathrm{O}\right)$ and iron oxides $\left(\mathrm{FeO}, \mathrm{Fe}_{2} \mathrm{O}_{3}\right)$ contents determine the firing temperature, the vitrification grade and the differentiation of ceramic dimensions [22]. The low amount $(<3 \%)$ of these oxides in $\mathrm{K} 1 \mathrm{M}$ explains the absence of vitreous phase at a low firing temperature (Table 2). In contrast, their relatively rich amount in MA2 and KG3 (>8\%) is responsible for a rapid densification.

The grain-size distribution of raw materials for building clay products influences in particular the behavior of the material during the shaping and drying processes. Grain-size distribution also affects the microstructure and the mechanical properties of fired materials [23]. The particle size distribution of the alluvial clay (KG3 and KB3) is variable with $7 \%$ to $37 \%$ of clay fraction, $20 \%$ to

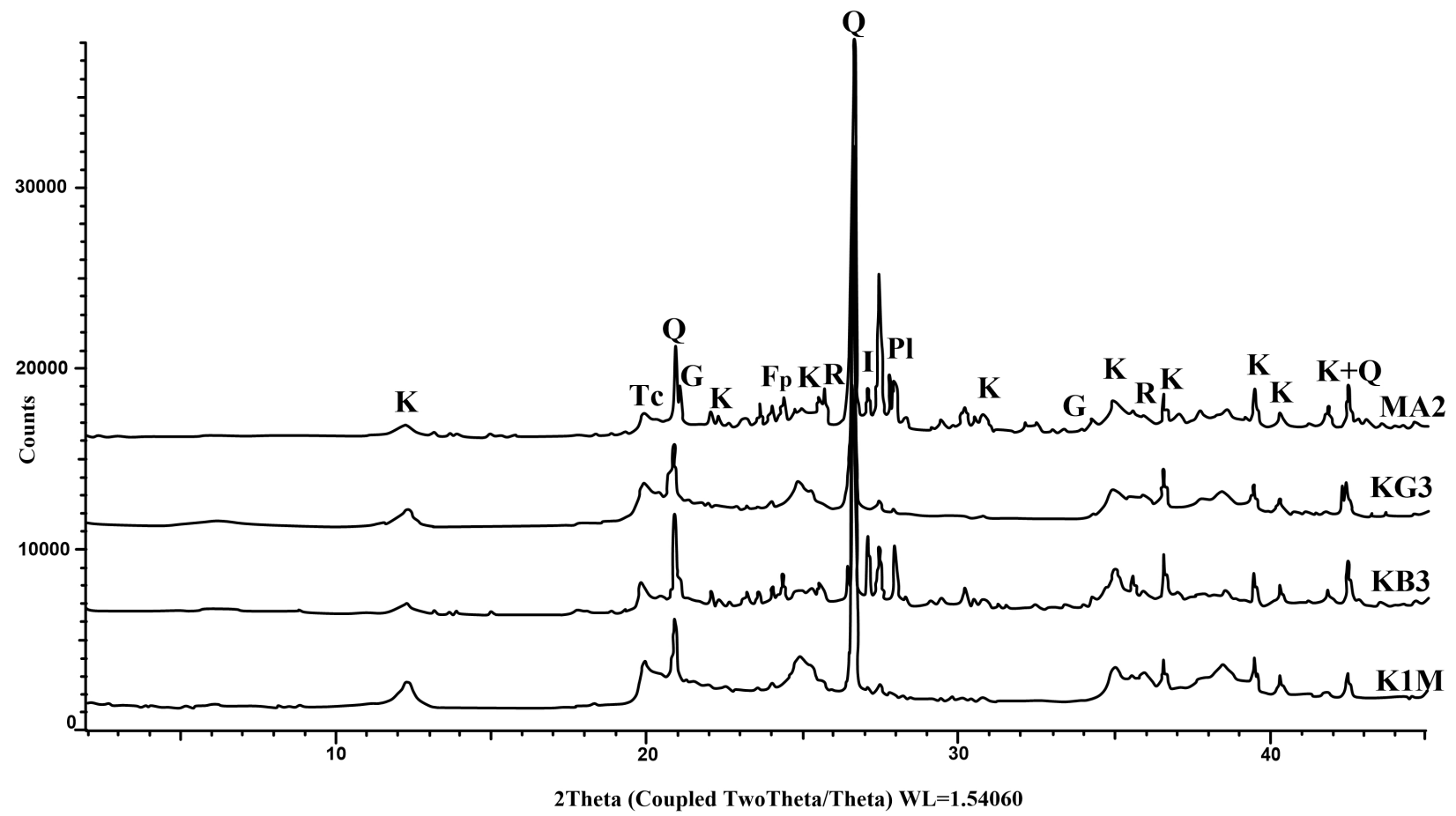

Figure 2. XRD of Bulk powder. $\mathrm{K}=$ Kaolinite; $\mathrm{Tc}=$ Total clay; $\mathrm{Q}=$ Quartz; Fp = Alkali-Feldspars; $\mathrm{Pl}=\mathrm{Plagioclase} ; \mathrm{I}=\mathrm{Illite} ; \mathrm{G}=$ Goethite; $\mathrm{R}=$ Rutile. 
Table 2. Particle size distribution (PSD, \%), Atterberg limits (\%) and chemical composition (major oxides, wt\%) of studied clay samples.

\begin{tabular}{|c|c|c|c|c|}
\hline \multicolumn{5}{|c|}{ Sample name } \\
\hline & $\mathrm{K} 1 \mathrm{M}$ & MA2 & KB3 & KG3 \\
\hline & \multicolumn{4}{|c|}{ Physical properties (\%) } \\
\hline Clay & 12 & 22 & 78 & 37 \\
\hline Silt & 51 & 20 & 7 & 45 \\
\hline Sand & 37 & 58 & 15 & 18 \\
\hline Wl & 42 & 43.6 & 59 & 103.7 \\
\hline Wp & 34 & 26.5 & 32 & 53.2 \\
\hline \multirow[t]{2}{*}{ Ip } & 8 & 17.1 & 27 & 50.5 \\
\hline & \multicolumn{4}{|c|}{ Chemical composition (wt\%) } \\
\hline $\mathrm{SiO}_{2}$ & 77.25 & 60.89 & 58.21 & 49.04 \\
\hline $\mathrm{TiO}_{2}$ & 0.16 & 1.3 & 3.04 & 1.72 \\
\hline $\mathrm{Al}_{2} \mathrm{O}_{3}$ & 14.67 & 20.16 & 22.28 & 22.75 \\
\hline $\mathrm{Fe}_{2} \mathrm{O}_{3}$ & 1.4 & 2.59 & 3.97 & 6.92 \\
\hline $\mathrm{MnO}$ & 0.01 & 0.01 & 0.02 & 0.02 \\
\hline $\mathrm{MgO}$ & 0.08 & 0.39 & 0.13 & 0.53 \\
\hline $\mathrm{CaO}$ & 0.06 & 0.63 & 0.18 & 0.46 \\
\hline $\mathrm{Na}_{2} \mathrm{O}$ & nd & 0.88 & 0 & 0 \\
\hline $\mathrm{K}_{2} \mathrm{O}$ & 1.08 & 4.64 & 1.29 & 0.74 \\
\hline $\mathrm{P}_{2} \mathrm{O}_{5}$ & 0.02 & 0.08 & 0.11 & 0.11 \\
\hline LOI & 5.2 & 8.42 & 10.78 & 17.71 \\
\hline$\left(\mathrm{A}+\mathrm{AT}+\mathrm{Fe}_{2} \mathrm{O}_{3}\right)$ & 1.22 & 6.54 & 5.57 & 8.65 \\
\hline
\end{tabular}

$\mathrm{A}=\mathrm{K}_{2} \mathrm{O}+\mathrm{Na}_{2} \mathrm{O} ; \mathrm{AT}=\mathrm{CaO}+\mathrm{MgO}$.

$78 \%$ of silt, and $15 \%$ to $58 \%$ of sand. The residual clays (K1M and MA2) present a less variable particle size distribution with on average $12 \%$ of clay, 51 of silt and $37 \%$ of sand. The raw clayey samples were plotted in the diagram of ideal particle size for bricks and tiles (Figure 3) as proposed by McNally [24]. The observed data distributions suggest that the samples K1M and MA2 would be applied to solid and performed bricks respectively. In contrary samples KG3 and KB3 are unsuitable for bricks manufacture: their high amount of fine fraction $(>80 \%$ of fraction $<20$ microns) would account for excessive shrinking during firing.

The plasticity of clay materials depends to its particle size distribution and mineralogy composition [24]. In Table 3, clay materials characterized by a plasticity index (PI) $8 \%-50 \%$ pertaining to the moderate (K1M), plastic (KB3 and MA2) and very high plastic group (KG3). They may be classified into the medium, plastic and very high plastic group [25]. The high plasticity of samples KB3 and KG3 (27\% - 50\%) is suitable for fine ceramic like pottery and sanitary 
ware. The studied samples were further plotted using the clay workability chart [26]. Samples KB3 and MA2 are acceptable for moulding in brick-making (MA2) and pottery (KB3) (Figure 4). Samples KG3 and K1M are rather inappropriate for extrusion due to their plasticity parameters, very high for KG3, very low for K1M. For those two samples, the addition of degreaser (KG3) or greaser $(\mathrm{K} 1 \mathrm{M})$ are respectively requested to reach the adequate plasticity for the fabrication of solid or perforated bricks and roofing tiles. Note that sample KG3 could be used to amend K1M and sample K1M to degrease KG3.

\subsection{Technological Properties of Fired Clays}

The results of open porosity, linear shrinkage, density and compressive strength as a function the firing temperature are presented in Figure 5. Compressive strength, density and linear shrinkage of all raw clay samples increase while open porosity decreases. Sample KG3 which has the highest clay fraction (KG3) shows high linear shrinkage (5\% - 16\%), high compressive strength (16\% - 23\%) and low open porosity (up to $21 \%$ ). The reverse trend is observed for sample K1M characterized by the lowest clay fraction. The relative high linear shrinkage in sample KG3 is in agreement with the occurrence of smectite and limits its application to produce bricks and tiles. Sample KG3 should rather be applied to amend non plastic clays like lateritic clays (e.g., K1M). The highest bulk density of sample KG3 $\left(1496-2126, \mathrm{~g} / \mathrm{cm}^{3}\right)$ explain its rapid densification as compared

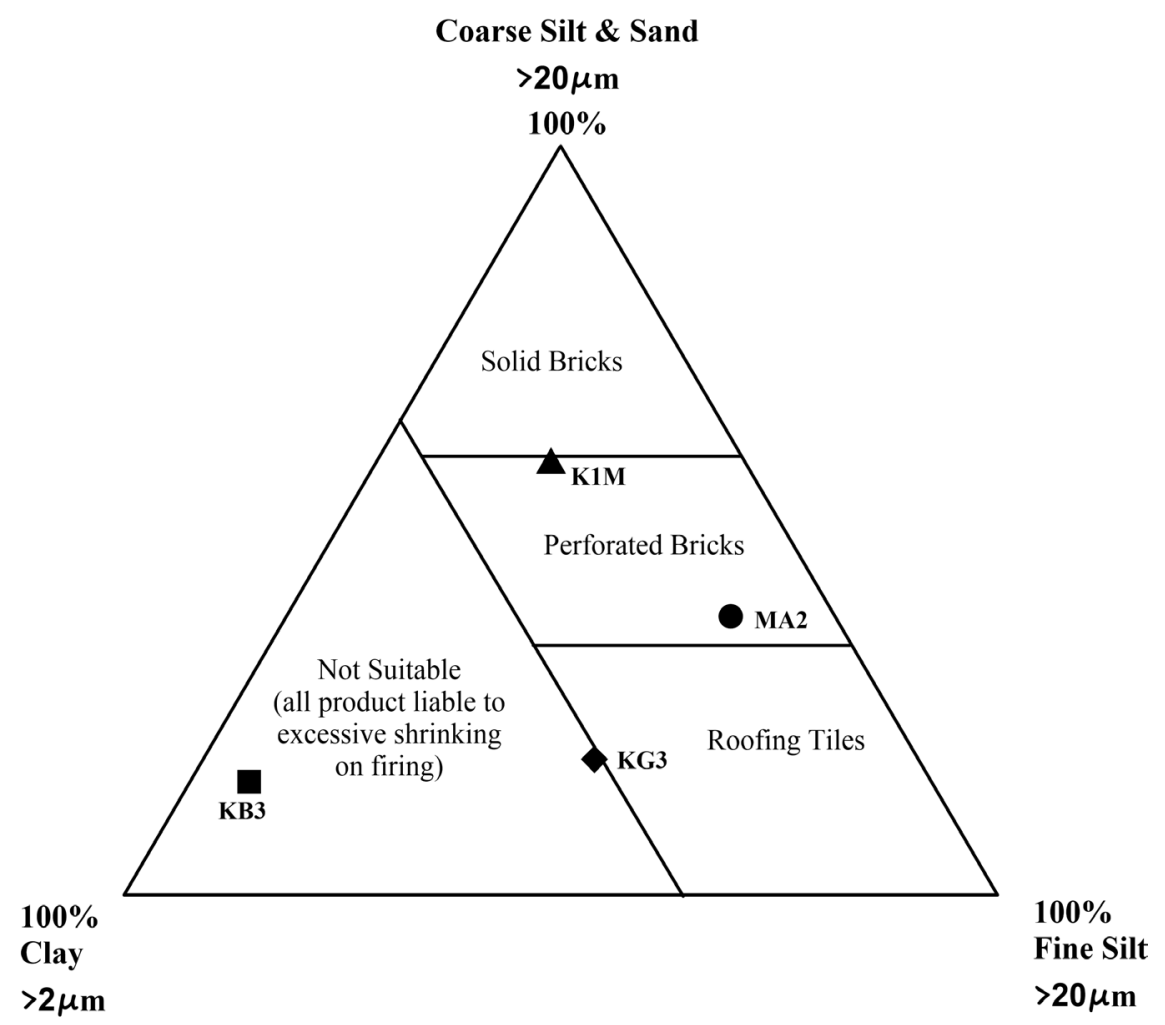

Figure 3. Evaluation of the suitability of raw material based on the diagram of the ideal particle size for bricks and tiles [1] [24]. 
Table 3. Physical and mechanical properties of fired products.

\begin{tabular}{|c|c|c|c|c|}
\hline \multicolumn{5}{|c|}{ Sample name } \\
\hline & $\mathrm{K} 1 \mathrm{M}$ & MA2 & KB3 & KG3 \\
\hline Temperature $\left({ }^{\circ} \mathrm{C}\right)$ & \multicolumn{4}{|c|}{ Linear shrinkage (\%) } \\
\hline 900 & 1.6 & 1 & 2.8 & 12.1 \\
\hline 950 & 2.3 & 1.1 & 4.3 & 8.2 \\
\hline 1000 & 0.9 & 1.8 & 3.7 & 15.3 \\
\hline 1050 & 0.7 & 4.2 & 3.6 & 17.1 \\
\hline 1100 & 0.6 & 5.5 & 8.7 & 25 \\
\hline 1150 & 0.6 & 10 & 12.6 & 37 \\
\hline \multirow[t]{2}{*}{1200} & 8 & 15.2 & 13.2 & 38.7 \\
\hline & \multicolumn{4}{|c|}{ Open porosity (\%) } \\
\hline 900 & 41.4 & 40.2 & 40.1 & 40.8 \\
\hline 950 & 41.3 & 40.95 & 40.1 & 42.8 \\
\hline 1000 & 41.3 & 40.05 & 40.1 & 40.2 \\
\hline 1050 & 41.6 & 38.4 & 40.4 & 41.2 \\
\hline 1100 & 41.7 & 36.6 & 37.4 & 34.8 \\
\hline 1150 & 41.7 & 33.9 & 33.4 & 21.9 \\
\hline \multirow[t]{2}{*}{1200} & 40.7 & 38.9 & 33.2 & 21 \\
\hline & \multicolumn{4}{|c|}{$\rho\left(\mathrm{g} / \mathrm{cm}^{3}\right)$} \\
\hline 900 & 1.523 & 1.562 & 1.593 & 1.496 \\
\hline 950 & 1.531 & 1.543 & 1.602 & 1.421 \\
\hline 1000 & 1.544 & 1.565 & 1.599 & 1.551 \\
\hline 1050 & 1.543 & 1.568 & 1.585 & 1.576 \\
\hline 1100 & 1.537 & 1.634 & 1.669 & 1.743 \\
\hline 1150 & 1.563 & 1.714 & 1.76 & 2.076 \\
\hline \multirow[t]{2}{*}{1200} & 1.583 & 1.794 & 1.753 & 2.126 \\
\hline & \multicolumn{4}{|c|}{$\sigma(\mathrm{Mpa})$} \\
\hline 900 & 2.7 & 3.7 & 6.2 & 9.3 \\
\hline 950 & 3.8 & 2.7 & 9.2 & 9.8 \\
\hline 1000 & 3.6 & 3.2 & 4.6 & 11.7 \\
\hline 1050 & 4 & 1.5 & 5.3 & 11.5 \\
\hline 1100 & 4.4 & 2.9 & 4.5 & 15.7 \\
\hline 1150 & 6.1 & 5.4 & 4.5 & 22.7 \\
\hline 1200 & 5.6 & 7.4 & 3.8 & 22.2 \\
\hline
\end{tabular}




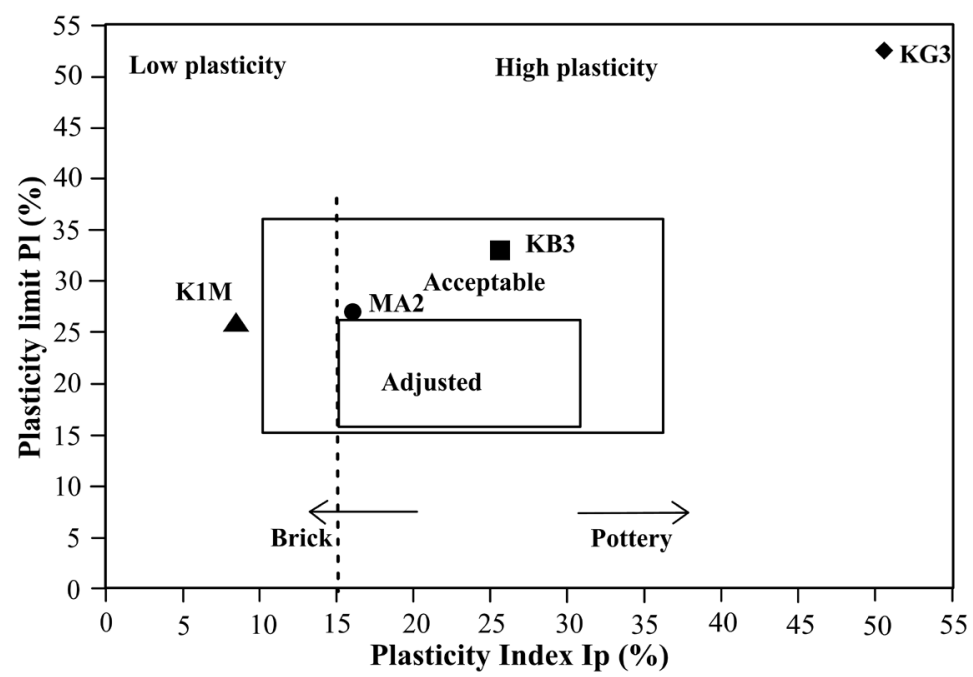

Figure 4. Evaluation of extrusion prognostic on the diagram of Bain and Highley [30]. Clay materials are suitable for pottery (KB3 and KG3) and brick making (K1M); samples KB3 and MA2 are acceptable for brick production by extrusion.
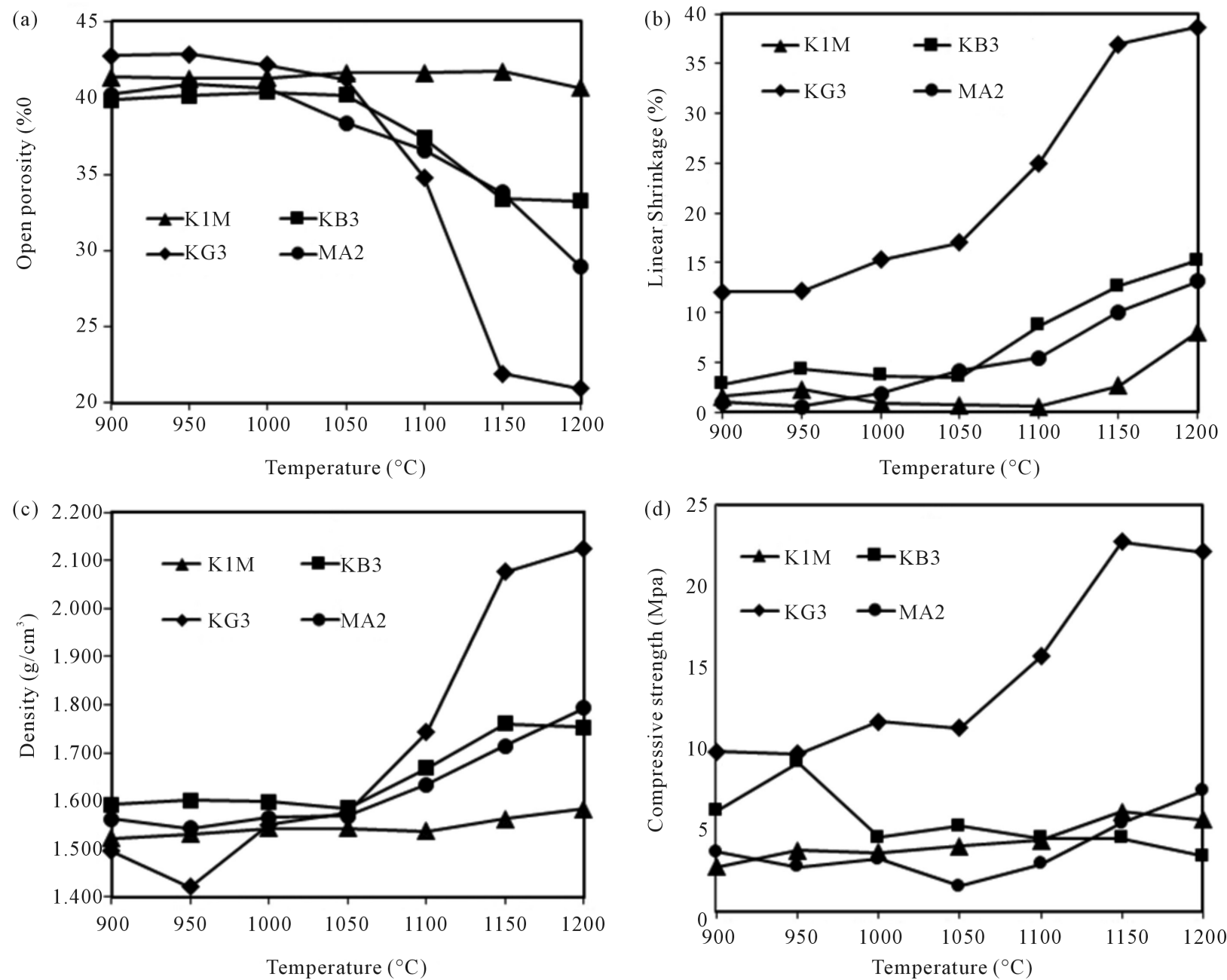

Figure 5. Evolution of physical and mechanical properties over $900^{\circ} \mathrm{C}$ to $1200^{\circ} \mathrm{C}$ heating: (a) Open porosity; (b) Linear shrinkage; (c) Density; (d) Compressive strength of the clays. 
with the other samples. This different densification behavior is probably induced by their mineralogy due to the relative abundance of impurities [27]. Sample $\mathrm{K} 1 \mathrm{M}$ presents only moderate values of bulk density in the fired properties at $900^{\circ} \mathrm{C}-1150^{\circ} \mathrm{C}$ due to its refractory behavior. A significant change of bulk density observed above $1050^{\circ} \mathrm{C}$ of samples KB3, MA2 and KG3 is associated with the sintering mechanism that promotes the densification of these samples and reduces the porosity.

An open porosity is closely related to the densification of the clay matrix. The decrease of open porosity is associated with a considerable liquid phase formation, which penetrated and isolated the adjacent pores [28]. A significant increase of compressive strength occurring at $1050^{\circ} \mathrm{C}$ and $1150^{\circ} \mathrm{C}$ (KG3) reflects most probably the inception of a glassy phase formation, with the predominance of viscous flow sintering and increased the material densification [28] [29]. Sample K1M shows a low variation of the open porosity in the temperature $900^{\circ} \mathrm{C}-1150^{\circ} \mathrm{C}(2-5 \mathrm{Mpa})$. This observation suggests a poor maturation of the firing products within this range of temperature [30]. Fluxing agents (feldspars and iron) were melted to reduce the temperature of vitrification and promote densification. The sintering temperature for sample $\mathrm{K} 1 \mathrm{M}$ above $1150^{\circ} \mathrm{C}$, agrees with its thermodilatometrical properties [4].

\section{Conclusions}

This study focuses on the composition and ceramic properties of four kaolinitic clays sampled from three deposits in Foumban (West Cameroon). The combination of mineralogical, physico-chemical and technological properties allow us to classify the raw clays according to their optimal application.

Technological properties of fired samples from both alluvial (KB3, KG3) and lateritic clays (K1M, MA2) are sufficient for bricks production. However, the addition of flux agent is recommended for sample K1M to decrease its sintering temperature. The low amount of fluxes, gives sample K1M a refractory firing behavior, which results in small variations in the properties above $1150^{\circ} \mathrm{C}$. Samples K1M and KG3 display an extrusion behavior (low plastic and high plastic clay respectively) not acceptable for building ceramics. Those samples require a proper adjustment of their sand-silt-clay ratio to improve their workability (i.e., addition of a plastic material for K1M and non-plastic material for KG3). The mineralogical composition of sample KG3 renders it inappropriate due to the high smectite content; this can be solved by some treatment or addition of quartz.

Further study of mineralogical transformations during firing can be carried out on Foumban raw clays (K1M, MA2 and KB3) to determine the influence of neoformation on the technological properties like porosity. They would provide valuable data regarding the choice of temperature, and the firing duration.

\section{References}

[1] Reeves, G.M., Sims, I. and Cripps, J.C. (2006) Brick and Other Ceramic Products. In: Reeves, G.M., Sims, I. and Cripps, J.C., Eds., Clay Materials Used in Construc- 
tion, Geological Society, Engineering Geology Special Publication, London, No. 21, 400-425.

[2] Manning, D.A.C. (1995) Introduction to Industrial Mineral. Chapman and Hall Edition, London. https://doi.org/10.1007/978-94-011-1242-0

[3] Vieira, C.M.F. and Sanchez Monteiro, R.S.N. (2008) Characteristics of Clays and Properties of Building Ceramics in the State of Rio de Janeiro, Brazil. Construction and Building Materials, 22, 781-787.

https://doi.org/10.1016/j.conbuildmat.2007.01.006

[4] Mefire, A.N., Njoya, A., Fouateu, R.Y., Nsandamoun, A.T., Nzeugang, A.N., Mache, J.R., Chinje, U.M., Pilate, P., Flament, P., Siniapkine, S., Ngono, A. and Fagel, N. (2015) Kaolin Occurrence in Koutaba (West-Cameroon): Mineralogical and Physicochemical Characterization for Ceramic Products. Clay Minerals, 50, 593-606. https://doi.org/10.1180/claymin.2015.050.5.04

[5] Weecksteen, G. (1957) Carte géologique de reconnaissance au 1/500000, feuille Douala-Est avec notice explicative. Direction Mines Géologie, Cameroun.

[6] Moundi, A., Wandji, P., Ghogomu, R.T., Bardintzeff, J.M., Njilah, I.K., Foumboure, I. and Ntieche, B. (2009) Existence of Quaternary Ankaramites among Tertiary Floods Basalts at Koutaba (Bamoun Plateau, Western Cameroon): Petrology and Isotope Data. Review of the Bulgarian Geological Society, 70, 115-124.

[7] Moore, D. and Reynolds Jr., R.C. (1997) X-Ray Diffraction and the Identification and Analysis of Clay Minerals. Oxford University Press, Oxford.

[8] Cook, H.E., Johnson, P.D., Matti, J.C. and Zemmels, I. (1975) Methods of Sample Preparation and X-Ray Diffraction. Data Analysis, X-Ray Mineralogy Laboratory, Deep Sea Drilling Project, University of California, Riverside. Contribution No. 74-5, 999-1007. https://doi.org/10.2973/dsdp.proc.28.app4.1975

[9] Boski, J., Pessoa, P., Pedro, J., Thorez, J.M., Dias, A. and Hall, I.R. (1998) Factors Governing Abundance of Hydrolysable Amino Acids in the Sediments from the N.W. European, Continental Margin $\left(47-50^{\circ} \mathrm{N}\right)$. Progress Oceanography, 42, 145-164. https://doi.org/10.1016/S0079-6611(98)00032-9

[10] Fagel, N., Boski, T., Likhoshway, L. and Oberhaensli, H. (2003) Late Quaternary Clay Mineral Record in Central Lake Baikal (Academician Ridge, Siberia). Paleogeography, Paleoclimatology, Paleoecology, 193, 159-179. https://doi.org/10.1016/S0031-0182(02)00633-8

[11] Kahle, M., Kleber, M. and Reinnold, J. (2002) Review of XRD-Based Quantitative Analyses of Clay Minerals in Soils. Geoderma, 109, 197-205. https://doi.org/10.1016/S0016-7061(02)00175-1

[12] Biscaye, P.E. (1965) Mineralogy and Sedimentation of Recent Deep-Sea Clay in the Atlantic Ocean and Adjacent Seas and Oceans. Geological Society of America Bulletin, 76, 803-832. https://doi.org/10.1130/0016-7606(1965)76[803:MASORD]2.0.CO;2

[13] ASTM-America Society for Testing Materials (1998) Standard Test Method for Particle-Size Analysis of Soils, ASTM D-422-63.

[14] ASTM-America Society for Testing Materials (2000) Standard Test Method for Liquid Limit, Plastic Limit, and Plasticity Index of Soils, ASTM D, 14.

[15] Gonzalez-Garcia, F., Romero-Acosta, V., Garcia-Ramos, G. and Gonzalez-Rodriguez, M. (1990) Firing Transformations of Mixtures of Clays Containing Illite, Kaolinite and Calcium Carbonate Used by Ornamental Tile Industries. Applied Clay Science, 5, 361-375. https://doi.org/10.1016/0169-1317(90)90031-J

[16] Carretero, M.I., Dondi, M., Fabbri, B. and Raimondo, M. (2002) The Influence of 
Shaping and Firing Technology on Ceramic Properties of Calcareous and Non-Calcareous Illitic-Chloritic Clays. Applied Clay Science, 20, 301-306. https://doi.org/10.1016/S0169-1317(01)00076-X

[17] ASTM-America Society for Testing Materials (2002) Standard Test Method for Compressive (Crushing) Strength of Fired Whitewares Materials, ASTM C773-88. Annual Book of Products, ASTM C373-88, Annual Book of ASTM standard.

[18] ASTM-America Society for Testing Materials (2002) ASTM Standard Test Method for Water Absorption, Bulk Density, Apparent Density and Apparent Specific. Gravity of Fired Whitewares Standard.

[19] Velde, B. and Meunier, A. (2008) The Origin of Clays Minerals in Soils and Weathered Rocks. Springer Verlag, Berlin and Heidelberg. https://doi.org/10.1007/978-3-540-75634-7

[20] Dondi, M., Iglesias, C., Dominguez, E., Guarini, G. and Raimondo, M. (2008) The Effect of Kaolin Properties on Their Behaviour in Ceramic Processing as Illustrated by Range of Kaolins from the Santa Cruz and Chubut Provinces, Patagonia (Argentina). Applied Clay Science, 40, 143-158. https://doi.org/10.1016/j.clay.2007.07.003

[21] Kornmann, M. (2005) Ingénieurs du Centre Technique des Tuiles et Briques, Matériaux de construction en terre cuite, fabrication et proprieties. Editions Septima, Paris, 33-34.

[22] Oikonomopoulod, K.I., Perraki, M., Tougiannidis, N. and Perraki, T. (2015) Clays from Neogene Achlada Lignite Deposits in Florina Basin (Western Macedonia, N. Greece): A Prospective Resource for the Ceramic Industry. Applied Clay Science, 103, 1-9. https://doi.org/10.1016/j.clay.2014.11.002

[23] .Ngun, B.K., Mohamad, H., Sulaiman, S.K., Okada, K. and Ahmad, Z.A. (2011) Some Ceramic Properties of Clays from Central Cambodia. Applied Clay Science, 53, 33-41. https://doi.org/10.1016/j.clay.2011.04.017

[24] McNally, G.H. (1998) Soil and Rock Construction Materials. CRC Press, London, 291-310. https://doi.org/10.4324/9780203476574

[25] Leonards, G.A. (1968) Predicting Settlement of Buildings on Clay Soils. Proceedings of Soil Mechanics Lecture Series on Foundation Engineering, Illinois Section of ASCE and Northwestern University, Evanston, Il, 41-50.

[26] Casagrande, A. (1948) Classification and Identification of Soils. Transactions of the American Society of Civil Engineers, 113, 901-930.

[27] Nzeukou, A., Kamgang, V., Medjo, R., Melo, U., Njoya, A., Lemougna, P. and Fagel, N. (2013) Industrial Potentiality of Alluvial Clays Deposits from Cameroon: Influence of Lateritic Clayey Admixture for Fired Bricks Production. Journal of Minerals and Materials Characterization and Engineering, 1, 236-244. https://doi.org/10.4236/jmmce.2013.15037

[28] Manoharan, C., Sutharsan, P., Dhanapandian, S., Venkatachalapathy, R. and Mohamed Asanull, R. (2011) Analysis of Temperature Effect on Ceramic Brick Production from Alluvial Deposits, Tamilnadu, India. Applied Clay Science, 54, 20-25. https://doi.org/10.1016/j.clay.2011.07.002

[29] Souza, G.P., Sanchez, R. and de Holanda J.N. (2002) Characteristics and Physical-Mechanical Properties of fired Kaolinitic Materials. Cerâmica, 48, 102-107. https://doi.org/10.1590/S0366-69132002000200009

[30] Bain, J.A. and Highley, D.E. (1978) Regional Appraisal of Clay Resources. A Challenge to the Clay Mineralogist. Proceedings of the IV International Clay Conference AIPEA, Oxford, 10-14 July 1978, 437-458. 